NBER WORKING PAPER SERIES

\title{
HOW ECONOMIC IDEAS LED TO TAIWAN'S SHIFT TO \\ EXPORT PROMOTION IN THE 1950S
}

\author{
Douglas A. Irwin \\ Working Paper 29298 \\ http://www.nber.org/papers/w29298 \\ NATIONAL BUREAU OF ECONOMIC RESEARCH \\ 1050 Massachusetts Avenue \\ Cambridge, MA 02138 \\ September 2021
}

I am grateful to Henry Wan for providing helpful advice and comments, Su Fen Liu for providing access to various documents, Marcus Noland for providing helpful comments, Grace Tsiang for providing me with information about her father, and several Dartmouth students for help with translations. The views expressed herein are those of the author and do not necessarily reflect the views of the National Bureau of Economic Research.

NBER working papers are circulated for discussion and comment purposes. They have not been peer-reviewed or been subject to the review by the NBER Board of Directors that accompanies official NBER publications.

(C) 2021 by Douglas A. Irwin. All rights reserved. Short sections of text, not to exceed two paragraphs, may be quoted without explicit permission provided that full credit, including () notice, is given to the source. 
How Economic Ideas Led to Taiwan's Shift to Export Promotion in the 1950s

Douglas A. Irwin

NBER Working Paper No. 29298

September 2021

JEL No. F13,F31,N75

\begin{abstract}
$\underline{\text { ABSTRACT }}$
Taiwan was perhaps the first developing country to adopt an export-oriented trade strategy after World War II. The factors usually associated with big shifts in policy-a macroeconomic crisis, a change in political power or institutions, lobbying by export interests, pressure from international financial institutions-were not present; it was ideas that were key. In 1954, economist S. C. Tsiang proposed that Taiwan boost export earnings rather than squeeze import spending to deal with its chronic shortage of foreign exchange. He recommended a currency devaluation to establish a realistic exchange rate and a market-based system of foreign exchange allocation to end the inefficient rationing by the government. Four years later, a leading policymaker, K. Y. Yin, fought for the adoption of Tsiang's proposal, helping clear the way for Taiwan's phenomenal growth in trade.
\end{abstract}

Douglas A. Irwin

Department of Economics

Dartmouth College

Hanover, NH 03755

and P̧eterson Institute for International Economics

and also NBER

douglas.irwin@dartmouth.edu 


\section{Introduction}

In the 1950s, few observers believed that developing countries could prosper under an export-oriented trade strategy. The disaster of the Great Depression and the disruption of world commerce during World War II seemed to demonstrate that openness to trade and dependence on foreign markets represented a risky proposition. Trade was not expected to be an "engine of growth"; export pessimism was widespread. The Economic Survey of Asia and the Far East 1959 declared that "rising exports are unlikely to play a leading role in the development process of most countries in the region" because "the momentum provided by the expansion in the export industries will be too small to bring about an adequate increase in total output” (United Nations Economic Commission for Asia and the Far East 1960, 101). Instead, "import substitution of manufactured consumer goods and food will be necessary in the primary producing countries of the region if they are to develop at a reasonably rapid rate" (104). ${ }^{1}$

Taiwan is generally recognized to be the first developing economy to reject such advice and adopt an export-oriented trade strategy. In the 1950s, it suffered from a chronic shortage of foreign exchange, which it tried to address with measures to limit spending on imports. This shortage was caused largely by a persistently overvalued exchange rate that led to excess demand for foreign exchange. To manage that excessive demand, the government opted for measures such as foreign exchange rationing, multiple exchange rates, import surcharges, and the like. These policies severely limited trade: Exports were less than 10 percent of GDP for most of the decade and imports a few percentage points higher, thanks to US foreign aid.

\footnotetext{
${ }^{1}$ Krueger (1997) describes the intellectual milieu of the period.
} 
In 1958, Taiwan changed course. It devalued its currency to eliminate the overvalued exchange rate, which suppressed exports. It freed up the market in foreign exchange, allowing exporters to keep or sell their earnings at a market-determined exchange rate, which meant that foreign exchange rationing could be terminated and the government could give up direct control over its allocation. These reforms led to a phenomenal growth in exports. Together with improvements in the investment climate, they helped propel Taiwan's economic miracle. $^{2}$

The beneficial outcomes of Taiwan's policy changes are well known; the story behind the decision to make these policy changes is not. ${ }^{3}$ What convinced the country's leaders to diminish the government's control over a valuable economic resource, a step firmly opposed by bureaucratic interests, and move forward with foreign exchange reform? What led policymakers to take the uncertain path of an export-oriented trade strategy when it was far from clear that such a policy would succeed?

This paper investigates the factors behind Taiwan’s commercial policy changes, in an effort to understand why such reforms were undertaken. Most discussions of policy change focus on the roles played by domestic producer interests, new political leadership and the opportunities created by economic crises, or international institutions and the conditionality they required for financial assistance. ${ }^{4}$ None of these factors was significant in Taiwan's case.

\footnotetext{
${ }^{2}$ Pritchett et al. (2016) find that Taiwan's growth acceleration began in 1962, lasted 32 years, and increase real per capita income by a factor of 36, the largest in their sample of rapid growth countries. Some of the leading studies of Taiwan trade and exchange rate policies include Hsing (1971), Lin (1973), Ho (1978), Galenson (1979), Little (1979), Scott (1979), Liang and Liang (1982), Lee and Liang (1982), and Panagariya (2019). In analyzing the policy changes in the late 1950s, Scott (1979) concludes that the crucial factors behind Taiwan's export growth were the tax rebate for exports, the removal of import restrictions, the adoption of a unified exchange rate, and the depreciation of the New Taiwan dollar.

${ }^{3}$ Haggard (1990) and Haggard and Pang (1994) examine the political and economic factors behind Taiwan's decision to move toward economic openness. They are closest in spirit to this paper.

${ }^{4}$ For discussions of the political economy of reform, see Bates and Krueger (1993), Williamson (1994), and Rodrik (1996).
} 
Domestic producer interests were stacked against any change: Taiwan’s exporters were weak and lacked political influence, while importers and producers competing against imports benefitted from the rents created by the existing trade regime. ${ }^{5}$ The country's political leadership and its political institutions were unchanged over this period. ${ }^{6}$ Having stabilized inflation several years earlier, Taiwan was not in the midst of a macroeconomic crisis. The International Monetary Fund (IMF) and the World Bank were not making policy-conditioned loans or engaged in structural adjustment lending at the time.

The apparent failure of these standard explanations of policy change leads one to consider the role of ideas. Economists are often wary of attributing changes in policy direction to individuals or groups motivated by ideas, looking instead for deeper structural factors, such as economic interests or institutions that shape those interests. But as Rodrik $(2014,205)$ has observed, "Because of their neglect of ideas, political economy models often do a poor job of accounting for policy change.” Of course, ideas by themselves are not enough; in order to be implemented, political actors within government must embrace them. The question is how that happens. ${ }^{7}$

This paper explores how the ideas of economists contributed to the shift in Taiwan's trade stance by examining the source and content of these ideas, the ways in which they were conveyed to government officials in a position to influence policy, and how the ideas came to

\footnotetext{
${ }^{5}$ In fact, interest group politics rarely explain big policy reforms. As Bates and Krueger $(1993,455)$ note, “One of the most surprising findings of our case studies is the degree to which interest groups fail to account for the initiation ... of policy reform."

${ }^{6}$ The reforms also failed to lead to any immediate changes in the country's leadership or institutions. As Ho $(1987,237)$ notes, "The economic reform that was initiated in the late 1950s did not alter any of Taiwan's basic economic or social institutions."

${ }^{7}$ Drawing on the findings of the Commission on Growth and Development, Brady and Spence (2010) highlight the role of political leadership in bringing reforms to fruition. Based on his long experience in Latin America, Harberger (1993) concludes that a few key policymakers—a "handful of heroes," as he called them—often drive policy reform. For a review of the role of ideas in policymaking, see Béland (2019).
} 
be implemented in the face of bureaucratic obstacles. Specifically, it examines how two economists (S. C. Tsiang and T. C. Liu) proposed a new foreign exchange regime to a highlevel policymaker (K.Y. Yin), who fought against strong opposition within the government to change Taiwan's policy regarding external trade, particularly as it related to foreign exchange and the exchange rate. Tsiang and Liu convinced Yin that an overvalued currency stifled exports and distorted imports because it forced the government to ration foreign exchange to resolve the underlying excess demand for dollars. The key elements of Taiwan's trade policy changes did not involve reducing import tariffs but rather adjusting the exchange rate and the disposition of foreign exchange. In particular, the ability of exporters to retain or sell their foreign exchange earnings at a market-determined rate provided a crucial stimulus to exports. In addition, the ability of importers to buy foreign exchange without getting government approval eliminated the scarcity rents associated with foreign exchange rationing and enabled any firm to purchase imports on a competitive basis. These changes shifted incentives away from securing rents by importing through privileged access to foreign exchange toward earning income through exporting to other markets. ${ }^{8}$

This paper is organized as follows. Section 2 describes Taiwan's trade regime in the 1950s, in which an overvalued exchange rate led to import restrictions and foreign exchange controls. Section 3 discusses the policy positions of Yin and Tsiang and describes how their relationship was formed and evolved. Section 4 examines the 1954 Tsiang-Liu memoranda that provided the basis for the 1958 foreign exchange reforms. Section 5 describes how Yin

\footnotetext{
${ }^{8}$ Taiwan's policy changes illustrate Balassa's $(1986,60)$ conclusion that "a review of [trade] policy reforms undertaken by developing countries fails to show that import liberalization would have played a central role in these reforms .... Rather, exchange rate reform has had central place, mostly involving the devaluation of the exchange rate, the elimination of multiple rates, and the adoption of a crawling peg."
} 
overcame opposition within the government and won support for the reforms in 1958. Section 6 examines the aftermath of reform.

\section{Taiwan's Foreign Exchange Regime}

In 1949, the Communist revolution in China drove the Nationalist government of General Chiang Kai-shek and his supporters off the mainland to Taiwan, a very poor island with little industry and few natural resources. The economic situation in Taiwan was dire. The war left the economy in ruins, and the recovery effort was strained by a massive influx of soldiers and refugees from mainland China. In the midst of a hyperinflation, the Nationalists adopted a stabilization program and introduced a new currency, the New Taiwan dollar (NT\$). This program ended the hyperinflation, but the government continued to spend large sums on national defense, resulting in persistent fiscal deficits and moderate inflation throughout the 1950s. ${ }^{9}$

Under the stabilization program, the value of the New Taiwan dollar was fixed against the US dollar. The continued rise in domestic prices meant that Taiwan's currency quickly became overvalued, leading to a balance of payments gap in which receipts from exports fell short of payments for imports. The overvalued currency meant that exports-two-thirds of which were sugar and rice-never exceeded 10 percent of GDP during the decade. Export earnings paid for only about 60 percent of imports; imports were 4-6 percentage points of GDP higher than exports only as a result of US foreign aid and military assistance. The imports made available through the additional foreign exchange—food, fuel, raw materials,

\footnotetext{
${ }^{9}$ See Makinen and Woodward (1989).
} 
and capital goods - were crucial to rebuilding the economy and maintaining the country’s precariously low standard of living.

The overvaluation of the New Taiwan dollar meant that demand for foreign exchange to purchase these imports was far in excess of the foreign exchange receipts earned through export earnings and aid inflows. The excess demand could be resolved either by changing the price of foreign exchange (devaluing the currency) or by rationing the quantity of foreign exchange (import controls).

Despite the chronic shortage of foreign exchange, the Chang Kai-shek government resisted any significant devaluation. The government would occasionally and reluctantly adjust the exchange rate but never enough to restore payments equilibrium or eliminate the black-market premium on foreign exchange. Government officials feared that a devaluation would drive up the price of critical imported goods and contribute to the inflation they were trying to keep in check. Furthermore, they did not believe that a devaluation would stimulate exports, because Taiwan’s two principal exports—-sugar and rice-were either fixed in quantity by international agreement or sold exclusively to Japan at prices and quantities determined in bilateral negotiations. Aside from these commodity exports, Taiwan had only a small base of nontraditional exports and the prospect that they would increase in response to a devaluation seemed slim. (The government introduced some limited export subsidies to compensate selected exporters for the unfavorable exchange rate.)

As it seemed unlikely that Taiwan could export its way out of its balance of payments problem, the government undertook measures to limit spending on imports. The principal method of regulating imports was foreign exchange rationing. Exporters were required to turn over all foreign exchange earnings to the central bank at the official exchange rate. The 
Foreign Exchange and Trade Control Commission (FETCC) had authority over the disposition of foreign exchange through quarterly commodity import budgets that were adjusted every few weeks depending on the level of foreign exchange reserves. ${ }^{10}$ Officials would screen requests for foreign exchange to ensure that scarce funds would not be wasted on what were deemed nonessential goods. ${ }^{11}$ Private entities applied to the FETCC to obtain a license granting foreign exchange. At the end of 1953, 3,729 applications for import licenses were being made each week by 2,226 firms. Only 7 percent of the foreign exchange applied for could be allocated, usually in small amounts. ${ }^{12}$

The import licenses gave the recipients special access to foreign goods that could be sold at a significant premium in the domestic market: 33 percent on cotton yarn, 48 percent on imported wheat flour, 152-63 percent on cotton piece goods, and 350 percent on woollen wear (Lin 1973). Firms began striving to obtain lucrative licenses to earn rents on imported goods rather than competing to reduce production costs and increase profits on domestic or foreign sales.

Rationing not only failed to solve the underlying foreign exchange shortage, it also led to controls in other areas of the economy. For example, the government blocked the entry of new firms and limited investment in sectors of the economy that were heavily dependent on imported intermediate goods. Such actions reduced future demand for foreign exchange, but

\footnotetext{
${ }^{10}$ The FETCC had a "wide range of functions concerning the setting of the exchange rate, determining import requirements, screening foreign exchange applications, and coordinating US aid, all of which gave it tremendous power" (Haggard and Pang 1994, 62-63).

${ }^{11}$ Imports were classified as permissible, controlled, suspended, and prohibited. Permissible imports included capital equipment and raw materials. Controlled or suspended imports were either temporarily banned or could be imported only by government agencies. Prohibited items were items that were considered dangerous or luxury products. Of the roughly 500 classified commodities, about 55 percent were permissible, 40 percent suspended or controlled, and 5 percent prohibited (Ho 1978). Of course, just because the importation of some foreign goods was permissible did not mean that they could be easily purchased.

${ }^{12}$ See Chien (1957). During the period 1951-53, the government allocated less than 20 percent of requests for foreign exchange (Lin 1973).
} 
they also protected the rents enjoyed by incumbent firms, which were insulated not just from foreign competition but from new domestic competitors as well.

Other measures were taken to limit spending on imports. Importers fortunate enough to obtain licenses were required to make an advance payment of 100 percent of the value of such goods, in addition to a 20 percent defense tax on top of the usual tariff. Of course, tariffs were not the binding constraint on imports, because the government controlled all spending on imports through the allocation of foreign exchange. ${ }^{13}$ Taiwan also used multiple exchange rates to discriminate between different import and export activities, depending on their importance, as determined by government officials.

The Chang Kai-shek government seemed comfortable with this situation, because its military leaders were more focused on defending the country against China than on promoting economic development (Peng 1992). Most of the country’s decision-makers were military leaders or engineers who lacked any background in economics and to whom the idea of a planned economy came naturally. ${ }^{14}$ Indeed, the ruling party, the Kuomintang (KMT), championed an interventionist state and state-owned enterprises dominated the economy. There was little interest in promoting the private sector, and the government had no real development strategy. ${ }^{15}$

\footnotetext{
${ }^{13}$ Taiwan's tariff schedule was initially taken from mainland China's, although it was inappropriate for its economy. China's tariffs tended to protect raw materials rather than finished goods; Taiwan imported raw materials to produce finished goods. The Nationalist government did not establish its own set of duties until 1955, when it raised the nominal tariff on finished goods from 20 percent to nearly 45 percent, to equalize them with the tariff on raw materials (Pang 1992).

${ }^{14}$ According to Tsiang $(1984,74)$, "During the 1950s, there were few signs of any sensible vision about Taiwan's future development, let alone any conscious strategies. . . Policies tended to be adopted in response to impending problems." Most leaders were "steadfast adherents of the command economy and the view that a planned economy and state control of industry were the best way to develop the economy" (Wu 2005, 64).

${ }^{15}$ As Haggard and Peng $(1994,48)$ note, "KMT power was accompanied, however, by a relatively coherent ideological perspective that championed an interventionist state and showed skepticism toward development of the private sector." Jacoby $(1966,137)$, notes that "nothing in their situation—nor in their economic philosophy—motivated Chinese officials to foster the growth of a strong private sector."
} 
Absent any distinctive ideology, government officials took a pragmatic, "problemsolving” approach to dealing with issues such as the foreign exchange shortage. They had no strong preconception about how to solve the ongoing problem; they viewed it as simply an issue to be managed and they therefore employed various ad hoc measures to ensure that Taiwan did not run out of foreign exchange. ${ }^{16}$

The government's complacent attitude stemmed in part from the fact that the United States provided millions of dollars in foreign aid. ${ }^{17}$ As long as Taiwan had US aid as a backstop, the government was not concerned about exporting enough to pay for imports.

\section{K. Y. Yin: The Pilot of Economic Development}

The government official most responsible for giving shape to—and ultimately changing the direction of-Taiwan’s economic policy was K. Y. Yin. From 1958 until his death in 1963, Yin was the country's leading economic policymaker and the driver of reforms. ${ }^{18}$

Trained as an electrical engineer, Yin worked in New York City during World War II, managing US military aid and procuring defense supplies for China. His record of efficiency

\footnotetext{
${ }^{16}$ Officials "managed Taiwan's economic transformation in a way of learning by doing rather than following any specific school of economics," according to Peng $(1992,94)$. The restriction of imports has sometimes been characterized as import-substitution industrialization, which Wu $(2005,104)$ views as wrongly implying that the government had a clear, well-thought-out development plan. "In actual practice,” Fei $(1992,7)$ notes, government planning "was little more than a rough classification of all industries according to aphorisms imagined by the bureaucrat."

17 “The regime's indifference [to economic development] stems partly from its unwillingness to accept their exile on the island of Taiwan, partly from the lack of market incentives to motivate officials, and partly from the fact that US aid covered the trade gap," according to Lewis (1993, 203).

${ }^{18}$ Yin was called the pilot of economic development in Taiwan (Li 1963). Yin was known as "very sharp, strong willed, and persistent" (Wang 2006, 87). "In the late 1950s and early 1960s, Yin was the most powerful economic bureaucrat because of his control of finance, US aid, foreign exchange, and trade. He was the economic tsar of his times,” according to Wu (2005, 59). See Pang (1992) and Liu (1987) for more biographical background.
} 
and effectiveness, along with a scrupulously clean record that was free of corruption, earned him the trust of Chiang Kai-shek. In 1949, Yin became vice chair of the Taiwan Production Board, where he helped manage public enterprises.

As an engineer with no training in economics, Yin was pragmatic and nonideological when it came to dealing with economic problems. ${ }^{19}$ He was aware that Taiwan's overriding problem was a lack of foreign exchange and knew that it could not depend on US aid forever. ${ }^{20}$ The pragmatic solution seemed to be to save foreign exchange by increasing domestic production and limiting imports, an approach that seemed more feasible than increasing exports to earn foreign exchange.

In 1952, Yin met Sho-Chieh Tsiang, a young Chinese economist employed by the IMF who began to shape Yin's views on economic policy. Tsiang earned an undergraduate degree in China and a B.Sc. (1941) and Ph.D. (1945) from the London School of Economics (LSE). During World War II, when LSE was temporarily relocated to Cambridge, Tsiang was exposed to both Keynesian theory from Cambridge dons and a more classical approach from his LSE instructors. ${ }^{21}$ Initially attracted to the Keynesian approach, Tsiang came to appreciate the market-oriented perspective of his teacher Friedrich Hayek, under whom he wrote a prize-

19 As Yin put it, he believed in "solving problems effectively and practically in a real environment, in order to optimize the economic welfare of the nation, without rigidly adhering to any school of thought. After all, as realworld problems are complex and many, one cannot expect to solve them by simply utilizing one school of thought and ignoring all others” (quoted in Kuo and Myers 2012, 109).

20 As Yin wrote in May 1952, “At present, Taiwan has not been able to balance the international payment yet, and it is the arrival of US aid that can compensate for the trade deficit. However, we should not rely on US aid for a long time. US aid can merely offer us a breathing space temporarily. We should use it only as a catalyst to revive our economy” (quoted in Pang 1992, 171).

${ }^{21}$ At the time, LSE was divided between a conservative group (Lionel Robbins, Friedrich Hayek, Dennis Robertson) and a younger cohort (Abba Lerner, Nicholas Kaldor) that was more sympathetic to the ideas of Keynes. Cambridge exposed Tsiang to the Keynesian ideas of Joan Robinson, Richard Kahn, and others. “To hear the traditional Marshallian theory and that of the Austrian School expounded by Robertson and Hayek and then to hear the same theories mercilessly attacked and ridiculed by Mrs. Robinson and others was a very thrilling experience,” Tsiang $(1989,2)$ recalled. 
winning dissertation. Like Hayek, he was generally opposed to interfering with the price system but saw a role for government in shaping the framework in which economic activity took place. ${ }^{22}$ After graduating from LSE, Tsiang became a professor at National Peking University. During the Communist takeover, he moved to the National Taiwan University. In 1950, he joined the research staff of the IMF in Washington. ${ }^{23}$

In 1952, while visiting Taiwan on home leave from the IMF, Tsiang was introduced to Yin. The meeting was not amicable: Tsiang saw Yin as a bureaucrat who lacked any economic framework to guide his decisions, and Yin viewed Tsiang as a theorist who had little sense for the practical problems facing policymakers. Tsiang gave Yin a copy of James Meade's short book Planning and the Price Mechanism: The Liberal-Socialist Solution (1949) and encouraged him to read it. ${ }^{24}$ In the book, Meade (1949, v-vi) argued for a mixed economy in which

"a large measure of state foresight and intervention is required to guide the economy from war to peace, to prevent inflationary and deflationary pressures, to ensure a tolerably equitable distribution of income and property, and to prevent or to control the anti-social rigging of the market by private interests, but

\footnotetext{
${ }^{22}$ His dissertation, written under the guidance of Hayek, won the Hutchinson Medal, awarded every two years to the best thesis in economics at LSE. Hsing $(1995,59-60)$ states that "Professor Tsiang's faith in economic liberalism was not free of the influence of the staunch champion of freedom, Friedrich A. von Hayek, his Ph.D. dissertation supervisor. . . . the price mechanism is the cornerstone of Tsiang's viewpoints on economic policy." ${ }^{23}$ He later became a professor of economics at the University of Rochester (1960-69) and Cornell University (1969-76). He is best known for taking a critical view of the conventional Keynesian theory of money and interest, rejecting the theory of liquidity preference for the loanable funds view.

${ }^{24}$ There are two stories about what Tsiang told Yin. In one version, Tsiang said, "This book primarily explains where the price mechanism works, how it saves the planners time and effort, and how it helps to solve complicated problems" (Hsing 1995, 61). In another version, Tsiang told Yin, "Do not underestimate James Meade, thinking he's just another bookworm or armchair theorist. During the Second World War, James Meade played a big role in the UK's economic policy as the deputy director [of the Economic Section of the Cabinet]. After the war he became the director, holding responsibilities in many issues. He has a very rich experience, much of which you can learn in this very book” (Wu and Peng 2012, 114ff). See also Tsiang (1992).
} 
that these objectives can be achieved in an efficient and a free society only if an extensive use is made of the mechanisms of competition, free enterprise and the free market determination of prices and output.”

In addition, Meade (1949, x) continued, "Protectionism must be reduced in all markets where import control is not absolutely essential for the balance of payments of the country in question" and "the depreciation of currencies of deficit countries" was the appropriate remedy for a payments imbalance.

Yin read Meade's short tract, supposedly the first economics book he had ever read, and was deeply impressed by the argument for a "planned market economy." Meade gave Yin a deeper appreciation for the price system and market competition (Hsing 1995; Wu 2005). According to his close associate K.T. Li (1963, 3), Yin came to believe that the "acceleration of economic development could be attained only by permitting the price mechanism and market forces to function properly.” As Li (1963, 3-4) put it:

"In his speeches and writings, [Yin] repeatedly emphasized: 'Let us be guided by the price mechanism of a free competitive market' and 'Let the distribution of resources be determined by the price mechanism.' Although he once said 'action must be taken by the government to ensure the best use of resources so that the benefits of economic development can be shared by all,' he disliked excessive intervention, which he believed would hamper economic development.”

Yin's views can be traced in his extensive writings during this period and they began to reflect the middle ground staked out by Meade. In a 1953 article, Yin said that Taiwan’s development goals “cannot be achieved in a laissez-faire economy” but that the government also should not centrally plan the economy. Instead, the government should promote industrial 
development for a certain period, through the provision of credit, foreign exchange, and technical guidance (Wu 2005). A year later, Yin (1954b, 7) argued that the government "should give its support to those industries which it thinks must be developed and which are in need of its support." At the same time, "there should be a limit to the support given by the government," and it was "still the responsibility of the industries themselves” to succeed:

"If normal development is to be attained, free competition must be maintained in order to attain higher efficiency, eliminate uneconomical production, and encourage the incentives of the various enterprises. Excessive support obviously hampers the operation of free competition and is bound to result in the creation of greenhouse industries dependent entirely upon the government. Such industries will merely be a burden on the Government and are not what we are hoping for.”

\section{The 1954 Tsiang-Liu Reports}

A hardworking and trustworthy administrator, Yin was named minister of economic affairs and chairman of the Industrial Development Commission in 1954. This post gave him a greater voice in the policy debate, as he worked closely with Vice President Chen Cheng, a military general who had oversight responsibility for economic affairs. ${ }^{25}$

Yin used his new position to invite Tsiang and his IMF colleague Ta Chung Liu to visit Taiwan and give advice on economic policy. ${ }^{26}$ They spent the summer of 1954 talking to

\footnotetext{
${ }^{25}$ Yin reported directly to Chen, as President Chiang Kai-shek "never interfered in economic affairs and barred the party from doing so" (Wu 2005, 58). Economic technocrats who were independent of the party and the military, such as Yin, enjoyed some autonomy and trust.

${ }^{26}$ Tsiang and Liu were independent consultants on leave from the IMF rather than part of an official IMF mission. Liu was an econometrician, who did not focus as much on international trade and exchange rates as Tsiang did. After growing up in China, Liu went to Cornell University in 1936 to study railway engineering.
} 
government officials and learning about the challenges they faced, particularly with respect to the balance of payments. The officials they encountered generally believed that a devaluation was undesirable, because it would not stimulate exports but would increase the price of imported materials and exacerbate inflation. Officials were also reluctant to leave the allocation of scarce foreign exchange to market forces, fearing that foreign exchange would be squandered on unproductive consumption goods.

Tsiang and Liu delivered two reports at the end of their visit that firmly rejected these views. The first, “Our Foreign Exchange Problem: A Preliminary Outline for Discussion,” dated September 9, 1954, stated, "There is nothing more important to the economy than an efficient allocation of our resources (including those for exports in exchange for imports) in such a way as to obtain the greatest possible total output” (Tsiang and Liu 1954a, 7). In their view, the main problem with the existing foreign exchange system was the "failure to take full advantage of international trade with the result of achieving less export and import trade, less employment and less government revenue than would otherwise be possible.” Tsiang and Liu (1954a, 5) noted that:

"The current system of exchange is characterized by (a) an overvalued multiple rate structure; (b) strict rationing of exchange proceeds for imports by a mechanism, while being constantly simplified as basic conditions improved, is still rather complicated and, to some extent, arbitrary; and (c) subsidies for exports, the rates of which are

\footnotetext{
After taking a class in economics from Fritz Machlup (who was a visiting professor), he decided to become an economist, earning his Ph.D. from Cornell in 1940. He joined the Chinese Embassy in Washington, DC, and attended the Bretton Woods conference as deputy commercial counselor. He returned to China in 1947 but left in 1948 to join the IMF. In 1958, he became a member of the faculty of Cornell University, where he remained until his death, in 1975. In the 1960s, he helped Taiwan develop national income accounts.
} 
determined by actual needs of the respective industries rather than for the purpose of encouraging more efficient exports and discouraging less efficient ones.”

Tsiang and Liu (1954a, 13) were highly critical of existing policy:

"The basic disadvantages of the present system of overvalued exchange rates are as follows: Firstly, exports fall short of the most desirable amount, with the corresponding reduction of imports which could have been obtained through advantageous exchange. Secondly, the excess of demand over supply of foreign exchange made it unavoidable to impose arbitrary quantitative restrictions on imports and to grant arbitrary subsidies to exports.”

Tsiang and Liu focused on the exchange rate as a key problem. Over time, the official exchange rate had become "progressively disassociated from the demand and supply conditions of different commodities, thus obscuring the relative efficiencies of different producers and traders, and distorting the relative values of the different commodities and factors of production from their relative importance to the economy.” The overvalued currency led to a complex system of import controls and export subsidies that resulted in an inefficient use of scarce resources. Even with the best of intentions and assuming administrative efficiency, the government could not avoid making arbitrary decisions about the disposition of foreign exchange, resulting in "an uneconomical allocation of resources." The overvalued exchange rate was a severe tax on exporters that depressed foreign exchange earnings. For example, the price of rice was so low that it was being used for animal feed rather than being exported to earn valuable foreign exchange. The limited export subsidies used to compensate for the overvalued exchange rate were set high for high-cost exporters and 
low for low-cost exports, thereby penalizing more efficient exporters and promoting less efficient ones.

Tsiang and Liu proposed scrapping the entire system of multiple exchange rates, import licenses, and export subsidies and creating an open market for foreign exchange with a single exchange rate for exports and imports and set at a competitive level. ${ }^{27}$ Unifying the exchange rate and devaluing would bring export earnings and import spending closer to balance and allow the government to dismantle the export subsidies, import restrictions, and other trade controls that were being used to balance Taiwan's international payments. Nonessential imports could be discouraged with high tariffs.

The second part of the report proposed using foreign exchange certificates in the transition to an open current account. ${ }^{28}$ Officials feared that an unfettered foreign exchange market would result in export earnings being lost to capital flight rather than used to pay for critical imports. Under the certificate scheme, exporters would turn over all foreign exchange earnings to the government at the prevailing exchange rate and receive a certificate for the foreign exchange earned. The certificate could be sold to any importer at a market-determined price, but it could be used only to import goods, not to move capital offshore. The use of exchange certificates would pave the way for an eventual open market in foreign currency.

\footnotetext{
${ }^{27}$ As Tsiang and Liu (1954a, 22) wrote, "It is our conclusion that the most suitable foreign exchange system for the present day Taiwan is to let the demand for foreign exchange for imports and other legitimate purposes and the supply of foreign exchange from exports and foreign aid establish through a free price mechanism, subject to the conditions discussed below, a uniform rate of exchange for both imports and exports that would secure an approximate equilibrium between the two." Their view was in harmony with IMF advice discouraging exchange controls and multiple exchange rates, but less in tune with the Fund's view of floating exchange rates. Tsiang (1957) later wrote about the positive experience of Peru under a floating exchange rate, a rare case in those days. ${ }^{28}$ Tsiang (1954) had written about foreign exchange retention schemes as a way of promoting exports. At the time, the IMF opposed exchange controls on current account transactions, as one of its major purposes was to ensure open current account payments (according to Article VIII(2)(a) of the IMF Articles of Agreement, "No member shall, without the approval of the Fund, impose restrictions on the making of payments and transfers for current international transactions”).
} 
The report addressed several fears that policymakers had about these ideas, which were unorthodox at the time. Tsiang and Liu rejected the notion that devaluation would fuel inflation and increase the domestic price of imported goods. They believed a devaluation would not be inflationary if accompanied by a dismantling of import controls, because the reduction in quota rents would offset the depreciation and hold down the price of imports. ${ }^{29}$ They also argued that a devaluation would redistribute income from wealthy urban importers to poor rural farmers. They were also optimistic that a devaluation could stimulate nontraditional exports. Although it was true that sugar and rice exports were largely fixed by international agreement, eliminating the overvaluation of the NT dollar would allow new firms in different industries to become competitive on world markets. A uniform, equilibrium exchange rate would be fair to all potential exporters and allow the market to establish which industries could be competitive and what products would be produced. ${ }^{30}$

The second memorandum, "Recommendation for the Revision of Our Foreign Exchange Policy,” dated November 18, 1954, was similar to the first but more forcefully argued. It also discussed the disadvantages of the overvalued exchange rate, the import licensing system, and export subsidies. Tsiang and Liu (1954b, 7) noted that "it is extremely difficult to prepare an import commodity budget that really corresponds to the communities demands" and that "import quotas become the object of struggle among all the importers and all those who are striving to be registered as importers.... Although the government's attempt to avoid personal discretion in the allocation of quotas is laudable, there is really no

\footnotetext{
${ }^{29}$ Tsiang (1980) elaborated on this proposition.

${ }^{30}$ Tsiang and Liu also advocated ending government controls on interest rates, which were kept artificially low with the goal of allowing borrowers to invest at lower rates in order to boost aggregate demand. The policy failed because it reduced the incentive to save, shrinking the pool of funds available for investment. The normalization of credit conditions was a driver of higher savings and investment rates in the 1960s.
} 
moral justification to using past import records as one of the criteria for allocations. Surely it is not justifiable on any moral ground that people who have once been given special favors by the government are always entitled to special favors from the government.”

The ad hoc use of export subsidies also led to "inefficient allocation of our product resources along different lines of export industries.... The pattern of exports would be distorted from that based upon our natural comparative advantages in production,” Tsiang and Liu (1954b, 4) argued. An undesirable consequence of discretionary export subsidies was that it "would divert a great portion of its managerial attention and energy to lobbying for subsidies instead of concentrating its energy to the improvement of the production and marketing of its products," Simply giving import quotas to exporters was also a "costly and ineffective” export-promotion scheme, as it gave firms an incentive to sell abroad at a loss simply to get a greater quota allocation in the future.

These two reports, along with discussions with Tsiang and Liu over the summer of 1954, had a powerful influence on Yin's thinking. ${ }^{31}$ This influence can be seen in an article Yin published that summer in which he identified three problems facing Taiwan: unrealistic multiple exchange rates were leading to a scramble for rents, incumbent firms had come to rely on excessive protection from imports, and monopolies had grown pervasive because of a lack of competition. ${ }^{32}$

\footnotetext{
31 "Even though Tsiang's and Liu's free-market argument was regarded almost as a heresy among most bureaucrats as well as among local economists, Yin was willing to listen to their suggestions,” Wu $(2005,68-69)$ reports.

32 As Yin $(1954,1-2)$ put it, "The quantitative restriction placed on imports due to the limited amount of foreign exchange available has resulted in a big difference between the market price and actual cost of imported commodities. The profiteers, with their eyes glued on profits yielded by this disparity and in the name of factories they have founded with negligible capital and symbolic or make-believe equipment, scramble for the privilege of obtaining foreign currency allocation or import quota.”
} 
Yin had become convinced of the need for policy changes along the lines proposed by Tsiang and Liu; others in government had not. ${ }^{33} \mathrm{P}$. Y. Hsu, the minister of finance and chairman of the FETCC, supported the existing regime. He believed that domestic industries were not capable of competing against imports and that the controls protected them from foreign competition. As a devaluation would fail to boost exports but would fuel inflation, he argued, the existing system of import controls and export subsidies should remain in place.

Yin had no authority over foreign exchange policy; that power lay with Hsu. Yin found it difficult to push forward with any significant policy changes, although he made some incremental progress in promoting exports of cotton textiles. In March 1955, Yin’s colleague K. T. Li suggested giving textile producers a rebate on the customs duty they paid on imported cotton, a proposal that others in government ridiculed. ${ }^{34} \mathrm{Li}$ succeeded in winning support for giving exporters a rebate on the customs duty paid on imported raw materials and intermediate goods, a measure that opened the door for discussion of other reforms, such as foreign exchange entitlements tied to export performance and tax rebates for imports of intermediate and capital goods for certain industries (Lin 1973).

Prospects for further reform were jeopardized when Yin was accused of corruption and forced to resign in July $1955 .{ }^{35}$ During the two years Yin was out of government, 33 As Tsiang later remarked, “Only K. Y. Yin really understood our ideas” (quoted in Kuo and Meyers 2012, 77).
34 "Mr. Li, do you think that our textile producers can compete with Japan's? Your proposal is totally
impossible,” said the Executive Secretary. “Are you suggesting that we make Taiwan into Lancashire?” joked
the chairman of the Bank of Taiwan (Wang 2006, 105). Li stood his ground, arguing that the proposal deserved a
chance to succeed or fail on its merits. As Li wrote in 1956, "Whatever Japan, Hong Kong and other exporting
countries could do, we should study it and reform ourselves accordingly. ... I hope that the government as well
as the private sector related to the export industry has a mutual understanding that exports come first. All
legislators sand policy executors should also follow in the spirit of 'exports first.' They should understand the
practical problems involved and loose up all restrictions. Then our problems in implementing policies will be
drastically reduced” (quoted in Wang 2006, 106-07).
35 Shortly before his resignation, Yin met with several economists, including Tsiang, Liu, and Mo-huan Hsing, a
University of Chicago-trained economist who held views similar to Tsiang's. According to Kuo and Myers
(2012, 110), "They criticized his reliance on the command economy’s policies to establish infant industries and 
Taiwan’s policies were largely unchanged. After being exonerated in September 1956, Yin was invited to rejoin the government in August 1957 as head of the Economic Stabilization Board. $^{36}$

\section{The 1958 Reforms}

Yin returned to the government as pressure was growing to address the chronic foreign exchange shortage. In 1957, the US Congress began to reduce military aid to Taiwan and shift foreign assistance from grants to loans for economic development. US officials encouraged Taiwan's leaders to think more about economic development, so that it could end its dependent on American aid.

These developments led President Chiang Kai-shek to establish a committee to address the foreign exchange situation. Chaired by Vice President Chen Cheng, the committee was split between opposing factions led by Yin and Hsu. ${ }^{37}$ Yin argued that excessive controls on foreign trade were the main obstacle to Taiwan’s development. He called for trade and exchange rate reform along the lines Tsiang and Liu had proposed three years earlier. These measures, he asserted, would increase export earnings and make up for the loss of US aid, making Taiwan more self-reliant. Hsu agreed that exports should be promoted but worried that a devaluation would ignite inflation and fail to stimulate traditional exports. Doubting that

his use of a regulated foreign-trade regime to obtain resources for his favorite among such industries. This gave him further pause for thought and he used his time away from government to read more about economics, becoming increasingly convinced that private enterprise was the way to improve the performance of Taiwan's economy."

${ }^{36}$ Yin was welcomed back to the government because he was a trusted technocrat who had no political ambitions. He was not even a member of the KMT. Yin and Li "were politically naïve in that they had no political ambitions and had no interest in politics. This boundary was crucial and was an important reason why the highest leaders trusted them. This trust was a precondition for acceptance and support of their ideas" (Wu 2005, 71). Yin was an extremely hard-working and effective administrator, but he was also known as impatient and demanding — “outspoken and quick-tempered,” according to Pang (1995, 100).

37 This account draws on Kuo and Meyers (2012) Wang (2008), and Lewis (1993). 
the United States would significantly reduce its financial support, he favored continuing with multiple exchange rates and foreign exchange controls as the best way to ensure that foreign trade would serve the national interest.

The divided committee was unable to reach a compromise. Chen was sympathetic to the technocratic economic reformers and had himself written about the dangers of dependence on foreign aid and the merits of self-reliance. ${ }^{38}$ The deadlock was broken in February 1958, when C. K. Yen, the head of the Council for US Aid, returned from a trip to the United States and confirmed that US assistance was going to be curtailed and that American officials supported the reform effort. Yen endorsed Yin’s approach and convinced Chen to support it. ${ }^{39}$ Chen informed President Chiang Kai-shek of the committee’s assessment and persuaded him to accept the change in policy. ${ }^{40}$

At the final committee meeting, in March 1958, Chen told Hsu of the president's decision and asked if he was willing to support the new policy. Hsu said that he could not and resigned his posts. Yen was appointed finance minister (a more political role), and Yin became the chairman of the FETCC (a more technocratic role). The FETCC was, of course, the very agency that had a vested interest in maintaining discretionary control over foreign

\footnotetext{
${ }^{38}$ He had even warned the president about problems with import substitution, noting that the government was not promoting development but "repressing the economy." Furthermore, he wrote, "with regard to foreign exchange and trade, [our] measures are inappropriate, and there are those in the debate who [welcome] the pain of restricting exports and encouraging imports" (quoted in Lee 2020, 474-75).

${ }^{39}$ In numerous instances, Yen made Yin's proposals palatable to other officials. Yin was hard-charging and forceful; Yen had a more agreeable personality. "Yen was calm, reserved, and subtle. He did not take issue with others, nor did he claim credit for his success. Yin was more resourceful and more willing to innovate. Yin initiated innovation and reform; Yen used his political finesse to persuade others to adopt Yin's suggestions” (Kuo and Myers 2012, 114).

40 "If Chiang Kai-shek had backed Xu instead of Yin, there would have been no reform,” according to Wu (2005, 142). "It was Chen Cheng who persuaded Chiang to accept Yin's reform policy. How he did so remains a mystery. ... . Chiang Kai-shek's and Chen Cheng's support for the reform bureaucrats was pivotal. Chiang was convinced by the bureaucrats that the reforms would help solve Taiwan's most serious economic problem, its worsening balance of payments, and enable Taiwan to forego American aid and become self-reliant” (62).
} 
exchange allocation. ${ }^{41}$ Yin later stated that "the goal I set when I became Chairman of the Foreign Exchange and Trade Control Committee (FETCC) was to abolish this organization” (Kuo and Myers 2012, 111).

Yin was put in charge of a task force to formulate the foreign exchange reforms. Within a few weeks, the plan was prepared and approved by the Legislative Yuan (Taiwan’s unicameral legislature) without notable opposition and with no public debate.

On April 12, 1958, the government announced the foreign exchange reforms. The multiple exchange rate system (with five different rates) was collapsed into a dual exchange rate system as a step toward unification. Exporters would be given tradable certificates for the foreign exchange they earned and receive rebates for the tariffs they paid on inputs. At a press conference announcing the policy, Yin stated that "this legislation [will] generate a chain reaction of activities to simulate exports.” With respect to the dual exchange rate, Yin said that "if circumstances allow, I intend to put in place a single exchange rate" (quoted in Kuo and Myers 2012, 85).

The April 1958 announcement was just the beginning of an ongoing reform process. In an October 1958 article, Yin warned that the foreign exchange reform was not a panacea and that it was "an incomplete revolution ... which continued to place too many products under import restrictions . . thus ... violating the fundamental spirit of our economic reforms" (quoted in Kuo and Meyers 2012, 89). As head of the FETCC, Yin abolished regulations that impeded imports and restricted exports, simplified procedures regarding the use of foreign exchange, and introduced tax rebates for exporters (Kuo and Myers 2012, 85). In November

\footnotetext{
${ }^{41}$ In addition to his post as secretary general of the Economic Stabilization Board, Yin served as chairman of the FETCC, vice-chair of the Council for US Aid, and the chairman of the board of the Bank of Taiwan. These posts put him at the apex of economic policymaking in Taiwan.
} 
1958, the government devalued the currency from NT\$25 per dollar to NT\$36 to close the gap between the official and the black-market exchange rates. In August 1959, the government merged the market-based exchange rate on certificates with the newly established official exchange rate. All export and import transactions were settled with exchange certificates at market-determined prices. As a result, in September 1959, the government terminated the quarterly import commodity budget and thereby ended its allocation of foreign exchange. All applications for imports accompanied by exchange certificates issued against exchange settlements of exports were automatically approved.

In July 1960, the government devalued again, to NT\$40, and the exchange rate was unified. The two devaluations almost eliminated the black-market premium on the currency (figure 1). Neither resulted in a significant increase in the overall rate of inflation.

\section{Figure 1}

Black market premium on Taiwan's exchange rate, 1950-67 percent

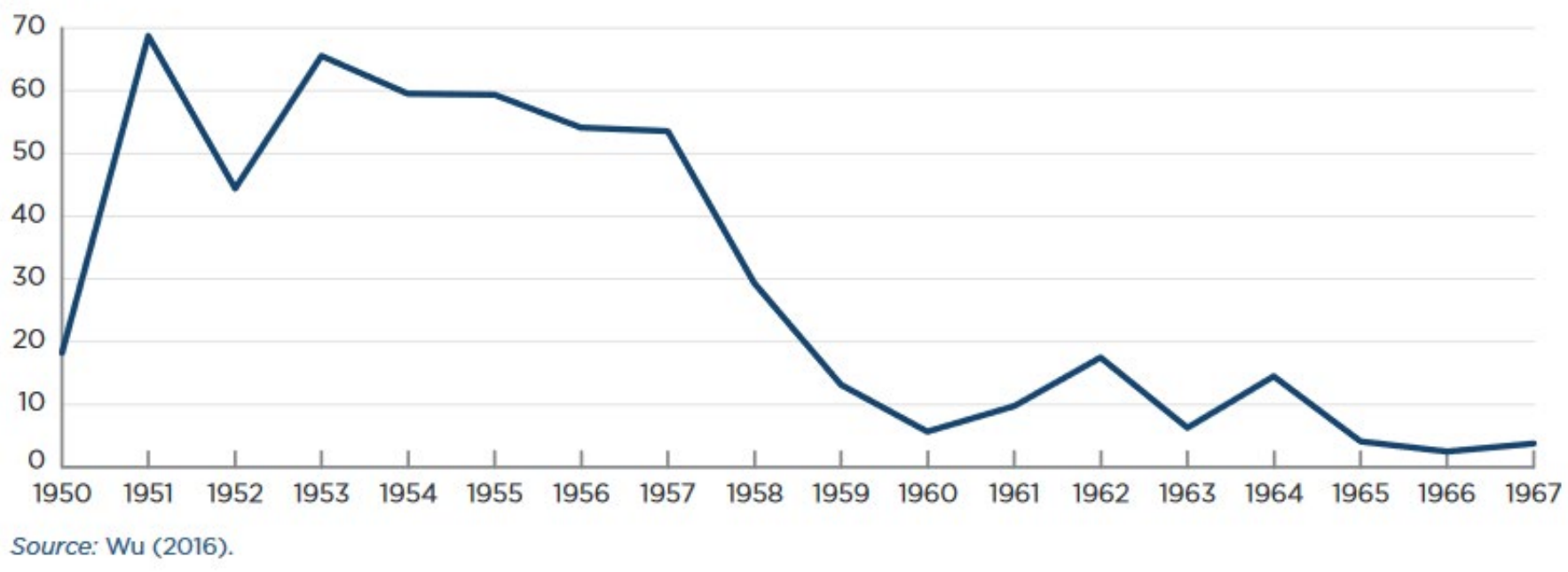

In explaining these reforms, Yin issued a blistering attack on the old system. Foreign exchange controls had been justified on the grounds that they promoted economic development, "but it actually turned out to be otherwise" (Yin 1959, 13). The problem with 
such controls is that they did "not permit the price mechanism to function" and required "arbitrary decisions" to be made about foreign exchange allocation (3). The complicated system had been "a heavy burden to both the control authorities and the public and constitute[d] a bottleneck in economic activities." They also "give rise to certain serious problems, such as misallocation of foreign exchange, unfairness, corruption, and abuse of authority.”

Yin $(1959,12)$ justified the devaluation on the grounds that the country "must do away with any unrealistic exchange rate.” As he put it, “There is no reason why we should subsidize consumption and penalize exports, offer excessive profits to importers and encourage those productive enterprises that are really unproductive.”42 The overvalued currency had become a source of windfall profits for importers, and producers sought to expand production (leading to excess capacity and inefficiency) simply to win a foreign exchange allocation. This "misuse and waste of resources" led to the importation of capital equipment at low prices not by the ultimate users but by resellers, such that "speculators reaped the full profit of the preferential rate while the real producers had to pay the market rate.” The overvalued currency was an obstacle to increasing exports and gave firms an incentive to focus on the small domestic market, with its limited investment opportunities.

The policy change, Yin $(1959,7)$ explained, was

"aimed at the gradual establishment of a free trade system by doing away with supply restrictions and multiple exchange rates and by permitting the price system to function. ... Importers may now freely decide what, when and how

\footnotetext{
${ }^{42}$ The failure to use market prices and the "unreality" of official exchange rates, Yin (1959, 3) continued, "lead to windfall profits for importers, excessive consumption, a drop in exports and abnormal development of certain productive industries. The net result is a distortion of the production structure and trade pattern, misuse and waste of economic resources and unfair distribution of wealth."
} 
much they want to import within the permissible list as dictated by market

demands. The price mechanism has been reactivated to a great extent and

arbitrary decisions made by administrative personnel have been reduced

correspondingly.... The partial reactivation of the market mechanism will lead

to free competition on the market, whereby domestic economic resources may

be more rationally utilized and more properly distributed, and waste of

resources made available with foreign exchange may be reduced or eliminated.”

Yin hoped that the policy would allow Taiwan to "reap some of the profits of international free competition and international division of labor.”

Of course, the government did not eliminate all intervention in trade. Yin $(1959,6)$ noted that "this relaxation of import control does not violate the government's protection policy to industries.” Taiwan did not relax many import controls or reduce tariffs until several years later. ${ }^{43}$

\section{Aftermath of Reforms}

Less than four years after Tsiang's and Liu's mission to Taiwan, Yin made their reform proposal government policy. How was it politically possible to uproot the existing

\footnotetext{
${ }^{43}$ As Haggard and Peng $(1994,76)$ put it, “The 'liberalization' of the trade and exchange rate regime was focused primarily on the exchange rate, and was driven by two considerations: both short-term and longer-run concerns about foreign exchange, and the concerns about the growth of a corrupt, rent-seeking complex around the foreign exchange control system. While this did result in some losses for those with preferred access to foreign exchange and weakened the exchange control portions of the bureaucracy, it was not accompanied by substantial liberalization except in those categories of goods required by exporters. The critical conflicts both within and outside the bureaucracy that might have arisen around import liberalization were effectively sidestepped.” See also Li and Liang (1982).
} 
foreign exchange system and establish a new one without encountering significant political backlash?

Under President Chang Kai-shek, the KMT was politically dominant. It had effectively suspended constitutional rules and given the president emergency powers. Having taken control of the island less than a decade earlier, the KMT did not have strong ties to existing business interests in Taiwan or depend on those interests for political support. ${ }^{44}$ Producer interest groups did not have much access to or influence over the country's top decisionmakers. The cabinet (Executive Yuan) had wide-ranging powers to implement policies without the support of interest groups or interference from the Legislative Yuan, which followed party dictates, giving top government officials relative autonomy in setting economic policy.

The economic reforms that began in 1958 were proposed by apolitical technocrats and did not originate from officials at the political level, who were dependent on the economic administrators for policy advice. ${ }^{45}$ The main opposition to the policy changes came from various agencies within the government (Haggard and Peng 1994, 73). Yin largely won that battle, in March-April 1958. The April 1958 reforms were made politically secure in June, when Chiang nominated Chen Cheng to serve as premier as well as vice president. As the KMT leader with responsibility for economic policy, Chen protected Yin and ensured that he could continue with reforms. ${ }^{46}$

\footnotetext{
${ }^{44}$ In fact, the reforms shifted lobbying by domestic manufacturers to the ministry of economy, where that lobbying took the form of requesting lower barriers to exports and additional tax relief for investment and exports (Lewis 1993, Li 1976).

45 According to Pang $(1992,77)$, "It was the interactions between the top political leadership and a group of economic policy makers rather than the votes by the members of the CSC and the Legislative Yuan that decided economic policy."

${ }^{46}$ As Chen Cheng said of him: "It seemed as if only he [Yin] was right.” (Wu 2005, 59).
} 
This political move occurred before the full results of the reform had become evident.

Political support for the reforms was reinforced by the subsequent outcomes. In 1959, exports rose 50 percent, led by nontraditional products. The devaluation made previously noncompetitive domestic goods more competitive on world markets and helped diversify Taiwan's exports away from sugar and rice toward labor-intensive manufactures. ${ }^{47}$ Cotton textiles jumped from \$2 million in 1957 to \$29 million in 1962, accounting for 13 percent of total exports (IMF 1963, II:24). ${ }^{48}$ The devaluation helped boost exports and alleviate the foreign exchange shortage — and it did not lead to an acceleration in inflation, as feared. Other policies that favored exports—including preferential interest rates on export loans, tax concessions for export production, rebates of taxes and import duties on raw materials imported for processing for export—also helped support the export expansion. ${ }^{49}$

The United States played little direct role in the 1958 reforms, but it soon provided support to encourage the reform process. In December 1959, the top US aid official in Taiwan proposed “an accelerated economic development program,” so that Taiwan could be weaned

\footnotetext{
${ }^{47}$ In 1957, sugar and rice accounted for 74 percent of Taiwan's exports; by 1962, their share had fallen to just 23 percent. Meanwhile, the share of nonagricultural exports jumped from 8 percent of total exports in 1957 to 28 percent in 1960. Lin (1973) estimates that exports accounted for a quarter of the growth in Taiwan's nonfood manufacturing production in the 1960s.

${ }^{48}$ Textile exports as a share of domestic production jumped from 1.4 percent in 1958 to 8.6 percent in 1959 and 20.0 percent in 1962 (Wu 2016).

${ }^{49}$ As Haggard and Pang (1994, 74-75) note, "While the exchange rate reform certainly played a central role in this process [of export expansion], it is important to underline a variety of complementary measures that were of a decidedly more interventionist sort. These interventions served the function of reducing the risk of shifting into the export business by providing premia to exporters and reducing information and transactions costs.” One question that has been raised is whether a period of import substitution was necessary for the later success of exports. Lin (1973) argues that without the protection policies of the import substitution period, the export expansion after 1958 could not have happened. By contrast, Wu (2016, 24-25) identifies the key policies for export expansion as the tax refund on imported materials, the devaluation, low interest loans, and the removal of other import restrictions. "If these policies were implemented earlier, there was no reason why Taiwan's high growth would not be started earlier," he claims. The "over-valuation of the NT dollar and high tax rate made it impossible for Taiwan to export cotton yarn and clothing. In the late 1950s, with the introduction of tax refund and depreciation of NT dollar, the comparative advantage of cheap labor emerged, and Taiwan was able to export textile products."
} 
off American aid. ${ }^{50}$ US advisers believed that Taiwan had to increase private sector investment, which in turn required an increase in domestic savings and a reduction in consumption. The policies they proposed included limits on defense spending, tighter monetary and fiscal policies to reduce inflation, tax reform, further exchange control liberalization, market-based utility pricing, financial market development, and the privatization of government enterprises. As an enticement to adopt these policies, the United States offered \$20 million-\$30 million in additional aid (Jacoby 1966).

Chen and Yin welcomed this offer, and two weeks later Yin responded with a 19-point “Plan for Accelerated Development.” The proposal focused on improving the investment climate, principally by reducing the heavy tax burden on investment, easing regulations on the conversion of agricultural land for industrial uses, and phasing out restrictions on capacity expansion and the establishment of new enterprises (Wang 2008, 140). President Chiang approved the package in January 1960, and the Legislative Yuan passed it in August (Kuo and Meyers 2012). Along with the second devaluation, in November 1960, these policy changes led to a significant increase in domestic and foreign investment and kept the export surge going.

Although the United States deserves some credit for encouraging the Taiwanese authorities to adopt these policies, Yin had already put the country on the path toward a more open economy. The US aid proposal came more than a year after the government had reformed the foreign exchange market and devalued its currency. Still, American aid enabled

\footnotetext{
${ }^{50}$ See the discussion in U.S. Department of State (1996, 643-46), available at https:/history.state.gov/historicaldocuments/frus1958-60v19/d323. The official was Wesley C. Haraldson, Director of the International Cooperation Administration (ICA) mission in Taipei; the ICA was a precursor to the US Agency for International Development.
} 
Taiwanese reformers to push forward with more changes, particularly with respect to investment.

Yin was the most important official who guided economic policy from 1958 until January 1963, when he died, at the age of 59. His close colleague K. T. Li continued the effort to open the economy. A 1962 visit to Trieste, a free port in Italy, gave Li the idea of establishing export processing zones (EPZ) in Taiwan, the first of which was opened in Kaohsiung in March 1965. Firms operating within the EPZ were exempt from paying duties on materials and components used in goods produced for export. The EPZ program attracted substantial foreign investment by multinational corporations. Exports and imports as a share of GDP soared after the mid-1960s (figure 2). ${ }^{51}$

Figure 2

Exports and imports of Taiwan as share of GDP, 1950-75 percent of GDP

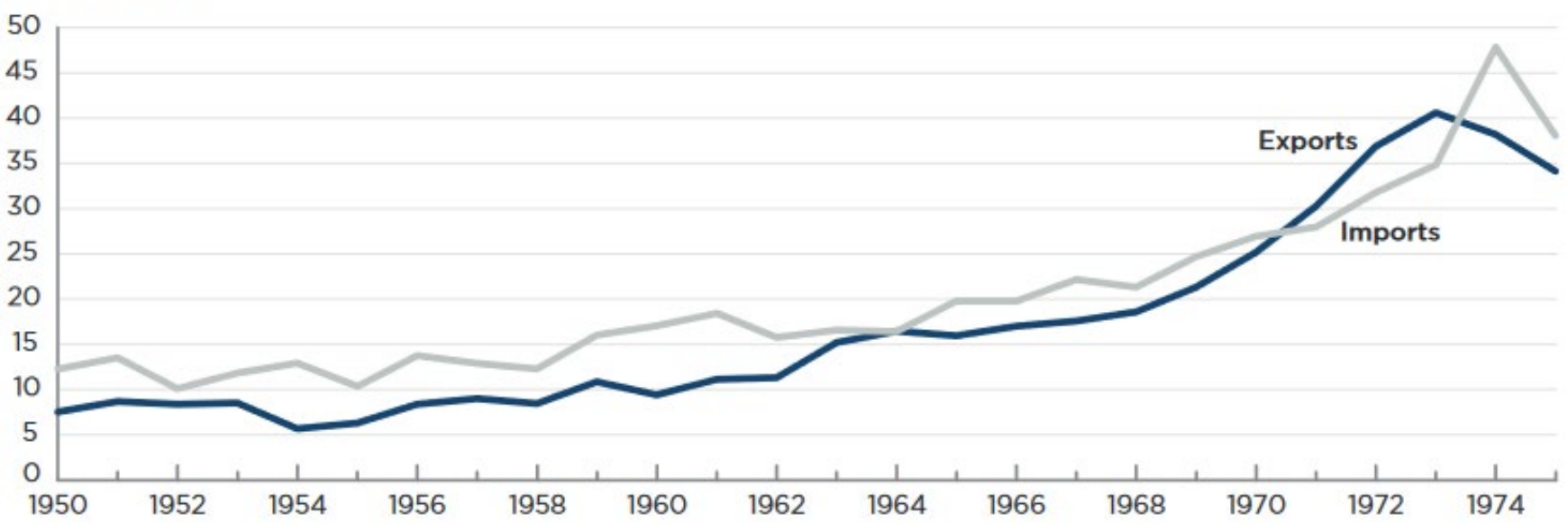
Source: Asian Historical Statistics: Taiwan, http://qcoe.ier.hit-u.ac.jp/enqlish/research/database/ashstat taiwan.html.

The 1958 policy reforms focused on the exchange rate and access to foreign exchange, but many barriers to trade remained in place. Access to foreign goods was more open in the sense that more firms had access to the foreign exchange necessary to purchase imports, but

51 The EPZs accounted for less than 10 percent of Taiwan’s exports in the late 1960s. 
the policy changes of the period did not always open up the domestic market to foreign competition. Only about 40 percent of commodity categories were free from import controls (quantitative restrictions) in the late 1960s, about the same as before the 1958 reforms ( $\mathrm{Li}$ and Liang 1982). Only minor changes were made to the tariff code when it was revised in 1965 and 1968. Taiwan's tariffs also remained relatively high, at about 20-40 percent on semifinished or finished manufactures and 40-75 percent on other goods. Of course, because of tariff rebates on imported intermediate goods for exporters, collected duties were much lower, in the $10-20$ percent range for most of the 1960 s (figure 3 )..$^{52}$ The failure to reduce tariffs is one reason why the remission of duties paid on imports used for exported goods was so important to the expansion of exports. The domestic market was not significantly opened up to foreign competition except when doing so served the interests of exporters. As Little (1979, 485) notes, Taiwan became "a kind of dual economy in which exports, but only exports, could be manufactured under virtual free trade conditions." ${ }^{53}$

At the same time, imports were significantly liberalized, in the sense that it became possible to import more products—and the foreign exchange to do so was more readily available. In May 1967, the advance deposit requirement for ordinary imports was cut from 100 percent to 50 percent and then, in August 1969, to 10-30 percent, thereby reducing the interest burden on importers. In 1970, the government sharply increased the range of

\footnotetext{
${ }^{52}$ The approach was one of phased-in gradualism, not a big bang. As Lin (1973, 94-95) notes, “To open an economy to international competition can only be a slow process, because it must work against the intertwining of vested ideas (included deep-rooted fear) and vested interests."

${ }^{53}$ Wade $(1993,148,153)$ contends that "Taiwan has departed significantly from the principles of almost free trade" and "quantitative restrictions [on imports] have been used extensively ... [and] have been administered through highly discretionary procedures." That said, he agrees that exporters "could obtain imported inputs quickly and at near world market prices” (156). See also Wade (1990).
} 
manufactured goods that could be imported; the share of permissible manufactured imports rose from 52 percent to more than 97 percent of import categories (Lin 1973).

When Yin and his colleagues began the policy shift, they did not anticipate the enormous changes that would occur as the incentive structure facing domestic producers changed from producing for the home market to producing for the world market. As Li (1988, 135-36) later put it:

"When the initial liberalization efforts were made, no one had any inkling that a more prosperous growth epoch was in the making. The early efforts were not ideologically motivated by any clear vision of the advantages of externally oriented growth, and there was only a vague awareness of the benefits of comparative advantage. The late 1950s reform measures were adopted for a pragmatic reason, namely, to reduce the reliance on American aid and to solve the problems of unemployment and foreign exchange shortages. ... Indeed, the term externally oriented growth was coined by economists only after its epochal significance became apparent.”

Yin always insisted that he was not motivated by ideological considerations but was simply seeking pragmatic solutions to long-standing problems. As he put it:

"In the past, some people criticized me as an extreme interventionist; then, some people said that I had changed my mind and become an advocator of free economy. As a matter of fact, my fundamental viewpoint is just "how to solve the problem efficiently and thoroughly in the practical circumstances.” It does not adhere to any specific theory but aims at seeking greatest economic interests for our country. The problem in actual situations are ever-changing and definitely cannot be solved by 
adhering to a certain theory or a certain assertion only.” (Quoted in Peng 1992, 96-

$97)^{54}$

Yet without the influence of Tsiang and Liu, Yin was unlikely to have understood how the policies that he eventually embraced would solve the actual problems he faced.

Tsiang believed that Taiwan’s experience held simple lessons for other developing economies. "By far the most important measure for the promotion of exports which a country with an overvalued exchange rate can adopt,” Tsiang (1965, 309) maintained, is an "adjustment of the exchange rate to an equilibrium level that would enable the country to balance its foreign trade without import restrictions and high tariffs. . . . None of the half measures, e.g. export bonus systems, multiple exchange rates, export-import link systems, etc., that may be devised by bureaucratic ingenuity to lessen the harmful effects of an overvalued exchange rate, really obviates the need for a devaluation." 55 Tsiang also invoked the Lerner symmetry theorem, which he learned at the London School of Economics, in saying that "it cannot be overemphasized that tax or restriction on imports is equivalent to a tax or restriction on exports.”

\footnotetext{
${ }^{54}$ As Yin said: "Regarding the controversy on liberalization and protection, I have no preconception about these out-of-date theories. If liberalization has more advantages, we should prefer liberalization; if protection can yield more advantages, we must choose protection. Policies are made for solving problems, therefore should be adopted to time, place, and issue. Economic policy-making must not be inflexible." He believed in "solving problems effectively and practically in a real-world environment, in order to optimize the economic welfare of the nation, without rigidly adhering to any school of thought. After all, as real-world problems are complex and many, one cannot expect to solve them by simply utilizing one school of thought and ignoring all others" (quoted in Kuo and Myers 2012, 109). Yin put forth his views in his four-volume work Wo-tui Taiwan ching-chi ti k'anfu (My Views on Taiwan's Economy) 1973 (in Chinese).

55 Tsiang $(1965,307)$ believed that having an overvalued exchange rate was "clearly [an] irrational policy" based on "misconceived beliefs about the advantages of exchange overvaluation," such as the notion that it might improve the terms of trade. "It is extremely irrational to maintain an overvalued exchange rate for the sake of a few primary exports to the detriment of all other exports and of the development of the country's resources in accordance with the principle of comparative advantage," Tsiang $(1965,307)$ wrote. He also attacked another misconception: "If the intention of the government in maintaining an overvalued exchange rate is to hold down the cost of living of wage-earners, then it is in effect attempting to subsidize the consumption of wage-earners in a very ineffective and wasteful way-by levying a heavy discriminatory tax on all exports, which is inconsistent with the avowed aim of promoting exports” (309).
} 


\section{Conclusion}

Taiwan was one of the first countries in the developing world to adopt an exportoriented trade strategy after World War II. The policy change was not driven by economic interests: Export sectors were neither large nor organized and did not play a major role in policy formation. The policy change was also not driven by new political leadership or changing institutions: The same party and political leadership remained in power throughout this period. The policy change was not based on foreign lending conditionality or an immediate crisis that demanded urgent policy adjustments, although the US decision to reduce foreign aid in 1957 began to put pressure on the government to make up for the lost foreign exchange.

The ongoing shortage of foreign exchange was the backdrop to the reform; the key idea of Tsiang that promoting exports rather than further restricting imports was a potential solution to the problem and that this could be accomplished by adjusting the exchange rate rather than by maintaining direct import controls. That solution was not ideologically based but was viewed as a pragmatic_-if contested—response to the problems facing policymakers. The decision to devalue and increase the incentive to export proved attractive because it also fit with the political objective of becoming less dependent on foreign aid from the United States. Taiwan's success with the new policy regime later made it an example to other economies considering similar policy changes.

Discussion of Taiwan's policies often becomes embroiled in debate over whether policymakers adhered to neoclassical economics or chose a heterodox path of industrial policy and state intervention. At least initially, the most important policy reforms were simply 
eliminating an overvalued exchange rate to give firms an incentive to export and allowing exporting firms access to inputs at world prices, even if the domestic market was still protected. “'Unshackling exports' that the East Asian countries had themselves at first shackled,” Hughes (1988, xv) noted, was a key element to Taiwan’s success. 


\section{References}

Balassa, Bela. 1986. Comment. In Economic Liberalization in Developing Countries, ed. Armeane M. Choksi and Demetris Papageorgiou. Oxford: Basil Blackwell.

Bates, Robert H., and Anne O. Krueger. 1993. Generalizations Arising from the Country Studies. In Political and Economic Interactions in Economic Policy Reform: Evidence from Eight Countries, ed. Robert H. Bates and Anne O. Krueger. Cambridge: Blackwell.

Béland, Daniel. 2019. How Ideas and Institutions Shape the Politics of Public Policy. New York: Cambridge University Press.

Brady, David, and Michael Spence. 2009. Leadership and Politics: A Perspective from the Growth Commission. Oxford Review of Economic Policy 25: 205-18.

Chien, C. T. 1957. The Problem of Foreign Exchange in the Economic Development of Taiwan. Industry of Free China (November), 2-15.

Fei, John. 1992. Taiwan’s Economic Development and its Relation to the International Environment. In Taiwan's Enterprises in Global Perspective, ed. N Wang. New York: M. E. Sharpe.

Galenson, Walter, ed. 1979. Economic Growth and Structural Change in Taiwan: The Postwar Experience of the Republic of China. Ithaca, NY: Cornell University Press.

Haggard, Stephan. 1990. Pathways from the Periphery: The Politics of Growth in the Newly Industrializing Countries. Ithaca, NY: Cornell University Press.

Haggard, Stefan, and Chien-Kuo Pang. 1994. The Transition to Export-Led Growth in Taiwan. In The Role of the State in Taiwan's Development, ed. Joel D. Aberbach, David Dollar, and Kenneth L. Sokoloff. Armonk, NY: M. E. Sharpe.

Harberger, Arnold C. 1993. Secrets of Success: A Handful of Heroes. American Economic Review 83: 343-50.

Ho, Samuel P.S. 1978. Economic Development of Taiwan, 1860-1970. New Haven, CT: Yale University Press.

Ho, Samuel P. S. 1987. Economics, Economic Bureaucracy, and Taiwan’s Economic Development. Pacific Affairs 60: 226-47.

Hsing, Mo-huan. 1971. Taiwan: Industrialization and Trade Policies. London: Oxford University Press for the OECD Development Centre.

Hsing, Mo-huan. 1995. Professor S.C. Tsiang’s Views on Economic Policies in Taiwan. In S. C. Tsiang: His Contribution to Economic Theory, ed. Tzong-shian Yu and Joseph S. Lee. Taipai: Chung Hua Institute for Economic Research.

Hughes, Helen, ed. 1988. Achieving Industrialization in East Asia. New York: Cambridge University Press.

IMF (International Monetary Fund). 1963. Article XIV Staff Report on China. SM/63/85, July 23. Washington. 
Jacoby, Neil H. 1966. US Aid to Taiwan: A Study of Foreign Aid, Self-Help, and Development. New York: Praeger.

Krueger, Anne O. 1997. Trade Policy and Economic Development: How We Learn. American Economic Review 87: 1-22.

Kuo, Tai-chun, and Ramon H. Myers. 2012. Taiwan's Transformation: Leadership, Property Rights and Institutional Change, 1949-1965. New York: Routledge.

Lee, James. 2020. American Diplomacy and Export-Oriented Industrialization on Taiwan. Journal of East Asian Studies 20: 463-83.

Lee, T.H., and Kuo-shu Liang. 1982. Taiwan. In Development Strategies in Semi-Industrial Economies. Baltimore, MD: Johns Hopkins University Press for the World Bank.

Lerner, A.P. 1936. The Symmetry between Import and Export Taxes. Economica 3: 306-13.

Lewis, Reese Phillip. 1993. The Origins of Taiwan's Trade and Industrial Policies. PhD dissertation, Columbia University, Department of Political Science. New York.

Li, K. T. 1963. The Man Who Led in the Industrial Development of Taiwan. Industry of Free China (February), 2-6

Li, K. T. 1976. The Experience of Dynamic Economic Growth on Taiwan. Taipei: Mei Ya Publications.

Li, K. T. 1988. The Evolution of Policy behind Taiwan's Development Success. New Haven, CT: Yale University Press.

Li, T. H., and Kuo-Shu Liang. 1982. Taiwan. In Development Strategies in Semi-industrial Economies, edited by Bela Balassa. Baltimore, MD: Johns Hopkins University Press for the World Bank.

Liang, K., and C. H. Liang. 1981. Trade Strategy and Exchange Rate Policies in Taiwan. In Trade and Growth of the Advanced Developing Countries in the Pacific Basin, ed. W. Hong and Lawrence B. Krause. Seoul: Korea Development Institute.

Lin, Ching-yuan. 1973. Industrialization in Taiwan, 1946-1972: Trade and ImportSubstitution Policies for Developing Countries. New York: Praeger.

Little, Ian M.D. 1979. An Economic Reconnaissance. In Economic Growth and Structural Change in Taiwan: The Postwar Experience of the Republic of China, ed. Walter Galenson. Ithaca, NY: Cornell University Press.

Liu, Alan P.L. 1987. Phoenix and the Lame Lion: Modernization in Taiwan and Mainland China, 1950-1980. Stanford, CA: Hoover Institution Press.

Makinen, Gail E., and G. Thomas Woodward. 1989. The Taiwanese Hyperinflation and Stabilization of 1945-1952. Journal of Money, Credit and Banking 21: 90-105.

Meade, James. 1949. Planning and the Price Mechanism: The Liberal-Socialist Solution. New York: Macmillan.

Panagariya, Arvind. 2019. Free Trade and Prosperity: How Openness Helps Developing Countries Grow Richer and Combat Poverty. New York: Oxford University Press. 
Pang, Chien-kuo. 1992. The State and Economic Transformation in Taiwan. New York: Garland.

Pritchett, Lant, Kunal Sen, Sabyaschi Kar, and Selim Raihan. 2016. Trillions Gained and Lost: Estimating the Magnitude of Growth Episodes. Economic Modelling 55: 279-91.

Rodrik, Dani. 1996. Understanding Economic Policy Reform. Journal of Economic Literature 34: 9-41.

Rodrik, Dani. 2014. When Ideas Trump Interests: Preferences, Worldviews, and Policy Innovations. Journal of Economic Perspectives 28: 189-208.

Schive, Chi. 1999. How Was Taiwan's Economy Opened Up? The Foreign Factor in Appraisal. In The Political Economy of Taiwan's Development in the 21st Century: Essays in Memory of John C.H. Fei, vol. 2, ed. Gustav Ranis, Sheng-Cheng Hu, and Yun-Peng Chu. Northampton, MA: Edward Elgar

Scott, Maurice. 1979. Foreign Trade. In Economic Growth and Structural Change in Taiwan: The Postwar Experience of the Republic of China, ed. Walter Galenson. Ithaca, NY: Cornell University Press.

Shea, Jian-Dong. 1999. The Liu-Tsiang Proposals for Economic Reform in Taiwan: A Retrospective. In Taiwan's Development Experience: Lessons on Roles of Government and Market, ed. Erik Thorbecke and Henry Wan, Jr. Boston: Kluwer.

Tsiang, S. C. 1954. The Economics of Foreign Exchange Retention Schemes (I) Partial Devaluation Aspect. Economia Internazionale 7: 508-30.

Tsiang, S. C. 1957. An Experiment with a Flexible Exchange Rate System: The Case of Peru, 1950-54. IMF Staff Papers 5: 449-76.

Tsiang, S. C. 1965. Tax, Credit, and Trade Policies to Promote Production and Export of Manufactures of Developing Countries. Part II. Journal of Development Studies 1: 295315.

Tsiang, S. C. 1980. Exchange Rates, Interest Rates, and Economic Development: The Experience of Taiwan. In Quantitative Economics and Development: Essays in Memory of T.C. Liu, ed. L. R. Klein, M. Nerlov, and S. C. Tsiang. New York: Academic Press.

Tsiang, S. C. 1984. Taiwan's Economic Miracle: Lessons in Economic Development. In World Economic Growth, ed. Arnold C. Harberger. San Francisco: ICS Press.

Tsiang, S. C. 1989. Introduction. In Finance Constraints and the Theory of Money, edited by Meir Kohn. New York: Academic Press.

Tsiang, S. C. 1992. Jiang Shuojie Xian Sheng Fange Wen Ji Lu [Reminiscences of Dr. S C. Tsiang]. Taipei: Institute of Modern History, Academia Sinica.

Tsiang, S. C., and T. C. Liu. 1954a. Our Foreign Exchange Problems: A Preliminary Outline for Discussion. September 9. Available in the Academia Sinica archives, Taipei.

Tsiang, S. C. and T. C. Liu. 1954b. Recommendation for the Revision of Our Foreign Exchange Policy. November 18. Available in the Academia Sinica archives, Taipei. 
United Nations Economic Commission for Asia and the Far East. 1960. Economic Survey of Asia and the Far East. New York.

US Department of State. 1996. Foreign Relations of the United States, 1958-60, Volume 19. China. Washington: Government Printing Office.

Wade, Robert. 1990. Governing the Market: Economic Theory and the Role of Government in East Asian Industrialization. Princeton, NJ: Princeton University Press.

Wade, Robert. 1993. Managing Trade: Taiwan and South Korea as Challenges to Economics and Political Science. Comparative Politics 25: 147-67.

Wang, Lutao Sophia Kang. 2008. K.T. Li and the Taiwan Experience. Taipei: National Tsing Hua University Press.

Williamson, John, ed. 1994. The Political Economy of Policy Reform. Washington: Institute for International Economics.

Wu, Hui Lin, and Hui Ming Peng. 2012. The Biography of Sho-Chien Tsiang. Haikou: Hainan chu ban she [in Chinese].

Wu, Tsong Min. 2016. From Economic Controls to Export Expansion in Postwar Taiwan: 1946-1960. RIETI Discussion Paper 16-E-028, Research Institute of Economy, Trade and Industry. Tokyo.

Wu, Yongping. 2005. A Political Explanation of Economic Growth: State Survival, Bureaucratic Politics, and Private Enterprises in the Making of Taiwan's Economy, 1950-1985. Cambridge, MA: Harvard University Press.

Yin, K.Y. 1954a. Adverse Trends in Taiwan's Economic Development. Industry of Free China (August), 1-5.

Yin, K.Y. 1954b. A Discussion on Industrial Policy for Taiwan. Industry of Free China (May), 1-14.

Yin, K.Y. 1959. A Review of Existing Foreign Exchange and Trade Control Policy and Technique. Industry of Free China, 2-21.

Yin, K.Y. 1973. My Views on Taiwan's Economy, vol. 2. Taipei: Economic Planning Council [in Chinese]. 